Centre for Evidence Based Medicine, Nuffield Department of Primary Care Health Sciences, University of Oxford, Oxford

Twitter @)KAronson Cite this as: BMJ 2022;376:0536 http://dx.doi.org/10.1136/bmj.0536 Published: 01 March 2022

\section{When I use a word .... Bioscience journals-an open and shut case?}

The term "open access" as applied to journals, widely and now inescapably used, is misleading. It implies that access to other journals is restricted. The important factor, however, is not openness or restrictedness, but who pays for access, readers and their sponsors (reader-directed access) or authors and their sponsors (author-directed access). Emerging evidence suggests that authors in low income countries can be disadvantaged by current author-directed fees in the open access framework, a problem that needs to be tackled. The recent "diamond" model may be beneficial, but it is much too soon to know.

Jeffrey K Aronson

\section{Open}

The word "open" ultimately derives from an Indo-European root, UPO, meaning under, up from under, and over. It is not unusual for some words to mean opposite things; altus in Latin, for example, means both high and deep. We see UPO in the prefixes hypo-, from the Greek ùró, and sub- from the Latin sub, both meaning under. In English, via Germanic routes, UPO gives us, among several other words, up and open. As befits its origins, "open" can be traced back to early Old English, i.e. to between the 7 th and 1oth centuries.

\section{Open access}

The noun phrase "open access” also has a long pedigree. It is first attested in English at the start of the 17 th century, when it had a sexual connotation. Then at the start of the 19th century it gained a wider remit, referring to people, places, and institutions. At the end of the 19th century it started to be applied specifically to libraries, referring, as the Oxford English Dictionary (OED) puts it, to "direct and unrestricted access for readers to the shelves on which publications are kept.” The first instance that I have found of the term as applied to access by general practitioners to medical services, such as diagnostic facilities, pathology, and physiotherapy, is from $1965 .{ }^{1}$ Other uses refer to access to narcotic drugs, ${ }^{2}$ contraception, ${ }^{3}$ orthopaedic appliances, ${ }^{4}$ and many other services and interventions. Open access to scientific data, including gene sequence data, ${ }^{5}$ was first mentioned in the $1990 .^{6}$ In all these cases the term “open access” was justified; previously access had been restricted.

\section{Open access publications}

The earliest reference that I have found to the specific use of the term in reference to free online access to published articles in journals is in the Budapest Open Access Initiative of $2001^{7}$ : "For various reasons, this kind of free and unrestricted online availability, which we will call open access, has so far been limited to small portions of the journal literature." This was soon followed by the establishment of the Public Library of Science. ${ }^{8}$

It is interesting that in early references open access was also called the "author-pays model,"9 recognising that what really matters is who pays.

\section{An allegory}

Three bookshops in a row open for business at the same time on East-West Street.

The first, to the east, is owned and run by Sacha and Sasha Smith. They run a conventional bookshop. Customers can browse the shelves, pick any book they want, and pay for it at the desk. The owners put up their shopfront sign: S and S Smith, Booksellers.

The second, to the west, is owned and run by Sam and Samantha Smith. They run a highly unconventional bookshop. Customers can browse the shelves, pick any book they want, and take it away without paying for it; these books have already been paid for by the authors. The owners put up their shopfront sign: S and S Smith, Booksellers.

The third, which sits between the other two, is owned and run by Sydney and Sidney Smith. They run a hybrid bookshop. Customers can browse the shelves and pick any book they want. Some books they will have to pay for, but not others, which they can take without payment. The owners put up their shopfront sign: Main Entrance.

All three bookshops are open all hours. It's not the openness that matters-it's who pays. In the first case it's the customer, in the second case it's whoever produced the book; in the third case it's a mixture of the two.

\section{Antonyms}

Antonyms of "open" include "shut" and "closed," "restricted" and "exclusive," and "hidden" and "concealed." Of these the most relevant is "restricted," in the sense that publications for which the reader has to pay are restricted to those who can afford to do so. The attraction of "open access" publication is supposedly that access is free to all.

But there is another sense in which publications are restricted, and the restriction applies to those who cannot afford to pay for open access.

There is no escape from the "open"/"restricted" dichotomy. Either (a) you the author or your sponsors, such as a grant giving body, can afford to pay the charge for publication in an open access journal or (b) you or your sponsors can afford to subscribe to a journal that isn't an open access one. Often those 
who can afford one can afford the other, while others can afford neither.

\section{Disadvantaged groups}

About 17 years ago, near the start of the open access movement I commented on open access. ${ }^{10}$ I suggested, for example, that if authors were expected to pay for publication, they might also expect to be paid as reviewers. There have been some calls for that, although it has not happened on any scale; but reviewers for journal submissions have become increasingly hard to find, and it may be necessary for some journals at least to consider paying reviewers. I also suggested that some journals might start making special offers, reducing prices or offering two for one; that has happened-my junk mail folder is replete with such offers from a wide range of journals, some of them, I suspect, predatory journals. Indeed, I predicted the rise of predatory publishers, although I didn't use that term, since it hadn't yet been invented, ${ }^{11}$ and I didn't fully appreciate the implications. I also suggested that some groups would be disadvantaged by their inability to pay, including unsupported undergraduates and postgraduates and junior hospital doctors. We now have some evidence about this.

A recent annotation in Nature ${ }^{12}$ informs us that papers published in open access journals have many fewer lead authors from low income regions than articles published in subscriber-pays journals. The annotation was based on the results of a study of over 37000 articles published in 38 journals and their corresponding mirror journals. ${ }^{13}$

The study showed that "The overwhelming majority of articles [in Parent journals or the Gold OA Mirrors] had lead authors based in high-income countries. ... [A] uthors from middle-income countries published proportionately few $\mathrm{OA}$ articles, but authors in low-income countries published almost entirely subscription-only articles in Parent journals." According to the authors, "these results strongly suggest that [author charges] are a barrier to OA publication by scientists from the low-income countries of the Global South [defined as the world's 'developing' or 'emerging' economies]."

\section{Conclusions}

It would be ideal if everything could be made free at the point of access, but someone has to pay somewhere along the line. That is inescapable.

What we should recognise is that the term "open" is misleading. What properly matters is who pays. The open access movement has been led by institutions in countries that can afford to pay, either for authorship or by subscriptions. The WHO's Health InterNetwork Access to Research Initiative (Hinari) ${ }^{14}$ has helped people in low income countries obtain publications by subscription, but those people have been disadvantaged as authors. Whether the latest innovation, the so-called "diamond" model, which involves no costs to either readers or authors, and which is supported by the UK's Joint Information Systems Committee (Jisc), ${ }^{15}$ will make any difference remains to be seen.

There is no ideal term. Instead of "open access," which implies that reader-pays journals are not accessible, we could say "reader-free access" for what we currently call "open access," acknowledging that all publications, both reader-pays and author-pays publications, are accessible to those who can pay and that we can give away access, whatever the model, to those who cannot. This, however, would ignore a distinction held in some quarters that "open" in this context also means free from copyright, which "free," paradoxically, does not. We could also subdivide different types of access, free or otherwise, into those that are paid for by the reader (by which I mean anyone who has access to the publication through a subscription, for which the readers themselves do not necessarily pay) and those that are paid for by the author (by which I mean anyone who is a co-author on the publication, for which the authors themselves do not necessarily pay).

Whatever terms we use, the disadvantages that some groups experience need to be addressed.

\section{Acknowledgments: I am grateful to Charles Whalley for comments on an earlier draft.}

Competing interests: JKA is an honorary fellow, president emeritus, and erstwhile vice-president publications of the British Pharmacological Society, which publishes three journals: The British Journal of Pharmacology and The British Journal of Clinical Pharmacology, which are hybrid journals, and Pharmacology Research and Perspectives, which is a gold open-access journal

Provenance and peer review: not commissioned; not peer reviewed.

Woodrow IH. Discussion on 'open access'. Practitioner 1965;194:412-4.pmid: 14269751

Westermeyer J. Narcotic addiction in two Asian cultures: a comparison and analysis. Drug Alcohol Depend 1977;2:273-85. doi: 10.1016/0376-8716(77)90005-9 pmid: 885069

3 Money J.Adolescent sexology and ephebiatric sexual medicine. Acta Endocrinol Suppl (Copenh) 1986;279:241-6. doi: 10.1530/acta.0.112S241 pmid: 3535335

4 Payne S, Ramaiah RS, Jones DT. Open access to orthopaedic appliances for general practitioners. Br Med J (Clin Res Ed) 1987;294:485-6. doi: 10.1136/bmj.294.6570.485 pmid: 3103740

5 Dickson D. Open access to sequence data 'will boost hunt for breast cancer gene'. Nature 1995;378:425doi: 10.1038/378425a0.

6 Andersen D, Axelsen NH, Riis P. Scientific dishonesty and good scientific practice. Dan Med Bull 1993;40:250-2.pmid: 8495601

7 Budapest Open Access Initiative. https://www.budapestopenaccessinitiative.org/read (previously www.soros.org/openaccess).

8 Trayhurn P. The public library of science and "open access" to the scientific literature. Br J Nutr 2002;87:1-2. doi: 10.1079/BJN2001495 pmid: 11895310

9 Delamothe T, Godlee F, Smith R. Scientific literature's open sesame?BM/2003;326:945-6. doi: 10.1136/bmj.326.7396.945 pmid: 12727740

10 Aronson JK. Open access publishing: too much oxygen?BMJ 2005;330:759. doi: 10.1136/bmj.330.7494.759 pmid: 15802718

11 Butler D. Investigating journals: The dark side of publishing. Nature 2013;495:433-5. doi: 10.1038/495433a pmid: 23538810

12 Kwon D. Open-access publishing fees deter researchers in the global south[Online ahead of print.]. Nature 2022. doi: 10.1038/d41586-022-00342-w. pmid: 35177842

13 Smith AC, Merz L, Borden JB, Gulick CK, Kshirsagar AR, Bruna EM. Assessing the effect of article processing charges on the geographic diversity of authors using Elsevier's "Mirror Journal" system. Quant Sci Stud 2022;2:1123-43. doi: 10.1162/qss_a_00157.

14 World Health Organization. Hinari Access to Research for Health programme. https://www.who.int/hinari/en.

15 Dobson H. A new approach to supporting scholarly communications: announcing the open access community framework (OACF). https://www.jisc.ac.uk/blog/a-new-approach-to-supportingscholarly-communications-announcing-the-oacf-24-feb-2022. 